\title{
An Analysis on Brand Image and Switching Intention of Flight Companies' Customers with Word of Mouth (WOM) as The Intervening Variable
}

\author{
Yasri $^{1}$, Yunita Engriani ${ }^{2}$ \\ 'Dept. of Management, Faculty of Economics, Universitas Negeri Padang, Padang Indonesia \\ $\triangle$ (e-mail) yasri_feunp@yahoo.co.id \\ ${ }^{2}$ Dept. of Management, Faculty of Economics, Universitas Negeri Padang, Padang Indonesia \\ $\bowtie$ (e-mail) yunitaengriani@gmail.com
}

\begin{abstract}
Brand image and intention to switch are two important factors for every company. Companies that already have a strong brand image tend to be preferred by customers and their intention to switch is lower. Factors influencing the two variables include word of mouth (WOM), customer satisfaction and complaint handling. The development of ICT encourages increased WOM and customer complaints. This study aims to analyze (1) the effect of customer dissatisfaction on the delivery of complaints, (2) the influence of dissatisfaction and complaint delivery to WOM, (3) the influence of dissatisfaction, complaint delivery, and WOM toward brand image, (4) the influence of dissatisfaction, WOM, brand image and switching cost toward customers intention to switch in aviation industry. The population of this study is all airline customers serving Padang-Jakarta and Jakarta-Padang routes. Population size in 2009 amounted to 276,000. The sample was selected using proportional random sampling. The sample size is 315 units. Data analysis technique was by using path analysis. The research reveals several important findings as follows. First, dissatisfaction does not have a significant effect to complaint delivery. Second, WOM is influenced by dissatisfaction and complaint delivery. Third, the effect of dissatisfaction is greater than complaints delivery to WOM. Fourth, brand image is affected by dissatisfaction, complaint submission, and WOM. Fifth, intention to switch is influenced by dissatisfaction, complaint submission, WOM and switching cost. Finally, WOM has the greatest influence for customer intention to switch. WOM is the intervening variable for brand image and customer intention to switch.
\end{abstract}

Keywords: customers' dissatisfactions, word of mouth, brand image, switching cost and intention to switch

\section{Introduction}

Since the introduction of aviation industry deregulation by the Indonesian government, there are emerging airlines in this country, among others; Lion air, Batavia air, Air Asia, Sriwijaya Air, Riau Air, besides those already incumbent like Garuda and Mandala. The growing number of airlines operating has led to an increasing number of customer choices. The bargaining position of customers is getting higher. This has led to increased competition among airlines. Companies compete to get customers so companies can exist in the market. Efforts to build competitive advantage are made both through low cost and by offering quality service.

To build competitive advantage, airlines need a close relationship with their customers. Companies need data and information about their target profile, wants and preferences. Implementation of relationship marketing enables the creation of customer loyalty, as relationship marketing seeks to establish, maintain, and strengthen relationships between companies and customers by viewing customers as partners (Dwyer, Schurr, and Oh as cited in Lincen, 2008). Loyal customers can solidify the source of corporate financing, as well as being strong word of mouth, have a lower tendency to move (intention to switch), less price sensitive, create business referrals (Bowen and Chen, 2001; Rowley and Dawes, 2000). 
Companies that can meet the needs and desires of customers well will have opportunities to be promoted by customers. Conversely, if customers feel dissatisfied it will create a negative WOM. Word of mouth (WOM) is formed among others from satisfaction or dissatisfaction and handling customer complaints. If customers are disappointed they have at least three possibilities actions. First, delivering it to the companies, second, sharing it to others people (negative WOM) or the last is switching service providers.

Increasingly high airline competition nowadays makes it easier for customers to switch from one flight to another. Various ways are done to discourage customers moving. Garuda for example offers member and frequency flayer to its customers to increase the use of this brand. Quality of service is also expected to have a big role in discouraging customers switching. A satisfied customer for a company's services will stay on it if another company is unable to offer better service.

Inhibiting factors of customer switching include brand image of products or services which is offered to customers. One important factor in customer decision making is the brand image. The Products that is chosen by customers choose are generally what's in their minds. Therefore, the real battle begins through the customer's mind. The brands that exist in the minds of customers will be chosen. If brand associations are firmly entrenched in the minds of customers then they are generally difficult to move to other brands. Building brand equity is an important strategy for retailers, encouraging multiple benefits and increasing the company's revenue and profitability compared to its competitors (Ailawadi and Keller, 2004).

Higher digital utilization causes customers to become stronger. They can easily access information and compare products of a company with other companies. If customers want to buy airline tickets, they can easily see the websites of every airline. The digital revolution also affects the dissemination of information from customers to other customers (WOM). This is also supported by the culture of Indonesian people who like to congregate and talk about various things. This condition causes higher information dissemination. Distribution of disappointment is much higher than customer satisfaction information.

Such a position causes the company have to be a market-driven company. Companies have to know and always have information about their customers' want and need. Therefore, customer complaints management and customer switching need to be managed as well as possible. Complaints can be negative affect for the company, but otherwise if it is managed well, it can surprise or impressed customers. A good company and customer relationships are important to manage because of the relationship the company will obtain valid and prompt information about the complaint, the intention to switch or changes in customer desires. Hart et al. (2000) states the importance of close communication with customers. Identifying customer needs through information or complaints from customers is important to the company. Therefore, service providers should respond to customer complaints briefly. The results showed that intention to switch was greatly influenced by the service provider's response to customer complaints.

Based on the background of the above problems, several problems in this research are as follows. First, to what extent the dissatisfaction of WOM, brand image, complaints and the intention to switch in flight customers? Second, to what extent the influence of complaint toward WOM, Brand image and intention to Switch of flight customer? Third, the extent to which WOM influences the brand image and intention to switch of airline subscribers? Fourth, to what extent the influence of the brand image toward the intention to switch of airline subscribers? Finally, to what extent influence of switching cost toward intention to switch of Indonesian airline subscribers?

Customer dissatisfaction will create a complaint or move sooner or later. Customers who complain will produce negative word-of-mouth but generally they do not complain to the service providers. Customer dissatisfaction will decrease the usage of customer service. The combination of negative word-of-mouth effects, switching, and consumption reductions will have an impact on company productivity and profitability. Thus, improving customer complaints management and 
learning from customer switching behavior will result in more benefits from customers (Edversson and Roos, 2006).

The risk of switching and reducing in re-purchase increases as well as the increase of negative WOM probability (Bearden and Oliver, 2001, 237; GrønhaugKjell, 2000; Richins, 2000). Good complaint handling results in satisfaction and increased loyalty, and decreases the likelihood of negative WOM (Bearden and Oliver, 2001, 236; GrønhaugKjell, 2000; Richins, 2000). This lowers the risk of moving and increases the likelihood of repeat purchase. Negative WOM is one result of customer complaint behavior. Hirschman (Nunziato, 2000) states that customers have two choices when dealing with a mismatch of expectations with performance received; i.e. complaining (voice) their dissatisfaction or leaving the company.

Aaker (2001) sees the image as the end result of all experiences, impressions, beliefs, feelings and knowledge of customers about the company or product. Nandan $(2005,273)$ considers that the image which is constructed by customers is their perception of the product. Chun and Davies (2006) state that the image is not created through advertising media, but rather through the customer experience using a product. O'Cass and Grace's (2004) concluded that word of mouth (WOM) is a dimension.

Keller (Nandan, 2005) states that the concept of brand image, based on the perception of a brand that is reflected by the brand association that is in the customer's memory. Furthermore, brand associations form brand attributes, brand trust and attitudes on the brand as a whole.

Communication in the form of positive WOM has been recognized as an extraordinarily valuable introductory communication to promote the company's products and services (Gremrel, Gwinner and Brown, 2001). Studies show that there is a relationship between complaints and WOMs (Bearden and Oliver, 2001; Richins, 1999; Singh, 1999; Ping, 2000; Nayor and Kleiser, 2000). Ping (2000) and also deals with satisfaction, switching costs and complaint behavior. So, there is a relationship between protests or complaints toward WOM and intention to switch. Hirschman (Menziato, 2000) looks at the situation of complaints when customers dissatisfied. A dissatisfied customer will choose some actions in various methods of protest; complaining, switching or leaving the service provider, or word of mouth (WOM).

Bateson and Hoffman (2000) suggest when certain levels of satisfaction are achieved after purchase and evaluation, the intention to do repurchase will be positive. Conversely, if the dissatisfaction occurs then the repurchase intention will be negative and customers do not want to buy the product any more. This condition will happen even though there are switching barriers, but satisfaction or dissatisfaction will affect the repurchase intention.

Dissatisfied customers tend to show negative expression to other customers or create negative WOM. Consequently, customer dissatisfaction leads to low customer loyalty (Lewis, 2001, 58; Newman, 2001; Caruana, 2002). The implication is that customer satisfaction and customer loyalty have a close relationship, and dissatisfaction will create an intention to switch. (Cronin \& Taylor, 2002; Oliver, 1999; Fornel, 2007; Caruana, 2002; Beerli et al., 2004; Boulding et al., 2000).

Customer dissatisfaction can be done in various ways that indicate frustration and anger, such as protesting, passing negative WOMs to friends and colleagues and complaining formally (Richins 1999; Singh, 1999; Singh, 1999; Strauss, Schmidt and Schoeler, 2005). Rust and Zahorik (1999) states that a great customer satisfaction creates a strong intention to repurchase the product. In the opinion of Anderson and Sullivian (2001) customer satisfaction at a high level will decrease the intention to switch to other service providers, so it will increase the repurchase intention of a product.

In general, the role of customer satisfaction and loyalty has a very close relationship. Customer loyalty is a function of customer satisfaction. This means that customer satisfaction will prevent customer movement (Fornell, 2007; Reichheld, 2000). Customer satisfaction and customer loyalty relationships are not always linear despite positive relationships (Fornell, 2007; Soderlund, 2000). High customer satisfaction is a solid foundation for retaining customers (Day, 2000). Customer 
satisfaction is also believed to affect the customer's desire to buy (Cronin and Taylor, 2002) and repeat their purchases (LaBarbera and Mazursky, 2003; Reichheld and Sasser, 2000).

Andreasen and Best (1999) reported that more than half of the non-complacent customers did not complain at all. Based on the Brief $(2001,1998)$ study only 20 percent of Americans complain of service dissatisfaction. The tendency of complaints is a function of imprecise or dissatisfaction and frustration (Strauss, Schmidt and Schoeler, 2005). Many of the unsatisfied customers do not complain directly to the company. Berry and Parasuraman (2007) stated that customers have a tolerance area where performance in this area will be accepted. Performance that exceeds the toleration area makes them impressed and loyal, when performance is below the toleration area will create dissatisfaction.

Factors to be considered in the behavioral analysis of complaints are risk, probability of success in complaints and complaints costs (Bearden and Teel, 2003, 24; Tarp, 1999; Richins, 1999; Andreasen, 2000). GrønhaugKjell and Gilly (2001) suggest that a greater tendency to complain about service has a link to the fact that service is difficult to standardize.

Griffin (2001) points out that the complaint that is considered and resolved quickly has a tendency to repurchase by 82 percent, otherwise customers who encounter major problems without complaints and the trend of repurchase is only 9 percent. Gilly and Hansen (2001) show that effective complaint handling results in customer satisfaction and loyalty. Complaints of customer dissatisfaction are a great tool for studying customer complaints and important factors to improve business contacts (Crask et al., 2008). Empirical evidence suggests a correlation between customer dissatisfaction over product or service failures and customer complaints (Bearden and Teel, 2003; Halstead et al., 2000).

Generally, a dissatisfied customer is not conveyed through complaints to the company (Kotler et al. (2007). Only about 5 percent of dissatisfied customers will complaint to the company. It means, approximately 95 percent of dissatisfied customer are not shared their complaints to the company. Doerpinghaus (2001) states that the disappointment of customer expectations, more than the failure of service quality resulting in complaints. Thus, the number of complaints is not significantly related to dissatisfaction (Andreasen, 2001; Bearden and Teel, 2003).

Switching cost means the costs incurred when the customer moves, including time, money and psychological costs (Dick \& Basu, 1999, 109), as well as the risks received, some of the possible losses suffered by customers when they move, such as financial, social, psychological and security (Murray, 2001).

Switching costs affect customer intention to switch. If the satisfaction is low and the switching cost also low then the customer will move (Rezabakhsh, et al., 2006; Kucuk and Krishnamurthy, 2007). However, when switching is difficult, customers tend to keep using a product (Reisch, 2003; Rezabakhsh et al., 2006, 32). Switching costs are also important determinants of customer switching (Jones, Mothersbaugh and Beatty, 2000; Sharma and Patterson, 2000). Burnham, Frels and Mahajan's (2003) in various industries found indications that switching costs, such as monetary losses and uncertainties with new service providers, determine the displacement and customer dissatisfaction.

Customers with poor service experience will switch or consider to switch to another provider (James and Richard, 2003; Lewis and Bingham, 2001). Switching cost is more effective than customer satisfaction, service quality, and pricing in retaining customers (Burnham, Frels and Mahajan, 2003; Jones, Mothersbaugh and Beatty, 2000).

\section{Methods}

This research was conducted on Indonesian airline customers serving Padang-Jakarta or JakartaPadang routes. Thus, the population of this study is all customers who have used passenger flights from Padang-Jakarta or Jakarta-Padang. The sample size was 305 units drawn with proportional systematic random sampling. The data collected are primary data. This data includes customer 
dissatisfaction, complaint (voice), word of mouth (WOM), brand image, switching cost and customers intention to switch. While the secondary data collected by the number of customers of each airline. Data collection technique is using questionnaires for primary data and documentation for secondary data. The questionnaire was designed by the researcher, so before it being used, it was tested the validity and reliability first. Data analysis technique used is path analysis.

\section{Results and Discussion}

The results obtained magnitude coefficient of influence as presented in Figure 1.

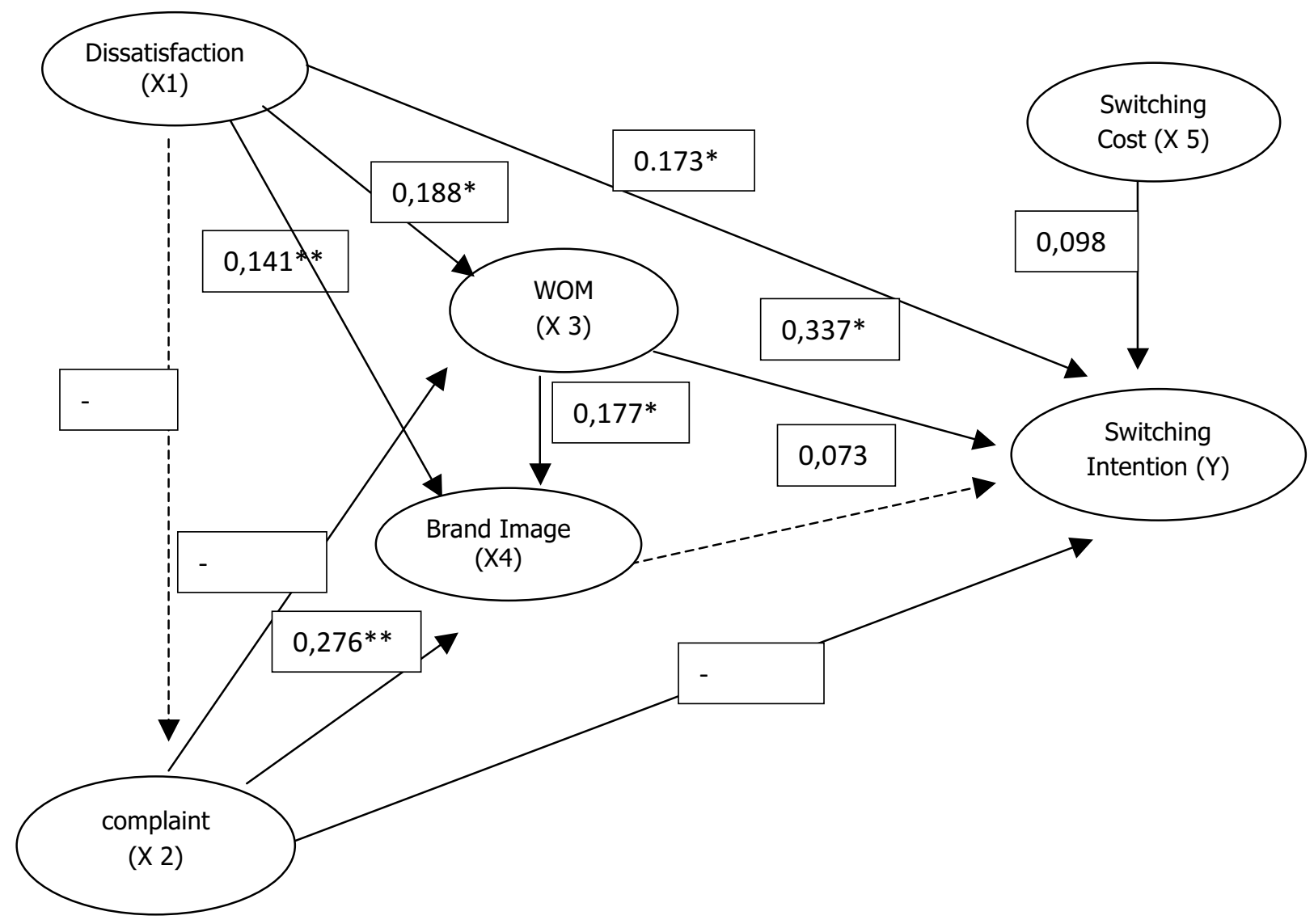

Figure 1 Research design analysis of brand image and intention to switch

Figure 1 shows that dissatisfaction has a positive and significant effect to word of mouth (WOM) and intention to switch. However, dissatisfaction has no significant effect on complaint (voice). While the complaints have a positive and significant impact on brand image, but significant and negative influence to word of mouth (WOM) and intention to switch. Word of mouth (WOM) has a positive and significant impact on brand image and intention to switch while the brand image has no significant effect on intention to switch. Furthermore, switching cost has a significant effect on customer's willingness to move.

The results of this research note that dissatisfaction does not significantly affect the complaints of Indonesian aviation customers. This means that airline customers do not complain about their dissatisfaction. Such customer behavior is due to several things. Habit of complaining is an inappropriate behavior in view of most people in West Sumatra. This means that a person complaining is considered unfair (unethical) by the community, so that this affects their complaining behavior. In addition, the complained dissatisfaction is usually occurred in a major dissatisfaction case. If it is only a small dissatisfaction, then they prefer not to deliver it to the company. Customers do not complain also due to poor complaints handling from the company so far. A poor complaintshandling experience will affect the behavior of complaining customers in the future. From their 
customer perspective, it is often blamed if they complain about the lack of service. The lack of customer complaints is also a result of the lack of equipment and customer ignorance of the way and channel of complaints. Generally, customers' dissatisfactions are not conveyed through complaints to companies. As Kotler et al. (2007) explain, only about 5 percent of disgruntled customers report to the company, which means that approximately 95 percent of customers' dissatisfactions are not shared with the company.

Andreasen and Best (1999) reported that more than half of the non-complacent customers did not complain at all. Based on the Brief's $(2001 ; 1998)$ study, only 20 percent of Americans complain about service dissatisfaction. The tendency of complaints is a function of imprecise or dissatisfaction and frustration (Strauss, Schmidt and Schoeler, 2005). Many of the unsatisfied customers do not complain directly to the company. Fornell (2007) states that companies should encourage customer dissatisfaction to be delivered in the form of complaints to the company. Doerpinghaus (2001) states that the disappointment of customer expectations, more than the failure of service quality that resulted in complaints. Thus, dissatisfaction is not significantly related to the number of complaints.

Dissatisfaction has a positive and significant effect on word of mouth (WOM), brand image and intention to switch. This means that if there is dissatisfaction then the customer prefers to deliver it to others (WOM) than to the company. When compared to the dissociation coefficient of these three variables, the influence on WOM has the greatest coefficient. If you notice the reason customers do not complain to the company, then most as the company's own fault. Whereas customer complaints about the dissatisfaction that occurs on the one hand will be very useful for companies to make improvements and on the other hand this condition is certainly very dangerous for Indonesian airlines. If the customer prefers to express his dissatisfaction to others then it means that the negative WOM will be formed.

Indonesian customers' habits of getting together and telling stories will broaden the spread of the negative WOM itself, likewise with the widespread use of social networking in Indonesian society. The amount of social network utilization such as Facebook, twitter, MySpace and other accelerate the dissemination of information from customers to colleagues.

Customer complaints have a negative and significant influence toward word of mouth (WOM). It means that the higher of complaints then the negative WOM will increase. This is in line with the habits of people who more likely to share negative complaints than the satisfaction or the positive one. The spread of negative WOM is greater than the positive WOM. This condition further indicates the need for grievance handling management at airlines. The airlines need to manage the negative WOMs in order to create benefit for the company in the future. The research shows that there is a relationship between complaints and WOMs (Bearden and Oliver, 2001; Richins, 1999; Singh, 1999b; Ping, 2000; Nayor and Kleiser, 2000).

Customer dissatisfaction also has a positive and significant impact on brand image. Although the magnitude of the coefficient is relatively smaller than the two variables above, but this situation describes the behavior of customers less profitable for airlines. This means that if customers encounter dissatisfaction over the company's service then the company's brand image is not good in the minds of customers. So, the habit of customers not to complain to the company has a bad effect, because it will create a negative WOM, a bad brand image and increase the intention to switch to another flight. Similarly, the effect of complaints on brand image that shows the positive and significant impact. It means that customer complaints will determine the company's brand image. This provides an opportunity for companies to handle complaints properly, so that customer dissatisfaction can be an impressive state to the customer. On the contrary if the handling of complaints cannot satisfy the customer, then the brand image will be even worse. Brand image that is formed can also be a positive image and also negative.

Word of mouth (WOM) has a positive and significant impact on the brand image of the airline. This indicates the magnitude of WOM's influence in shaping the brand image. If the positive WOM 
occurs then will form a positive brand image, and vice versa if the developing WOM negative. The results of this study are in line with the views of O'Cass and Grace (2004) concluded that word of mouth (WOM) is a dimension that often occurs and affect the brand image of a product. Based on the results of the study note that the magnitude of direct influence of dissatisfaction on brand image is 1.99 percent and the indirect effect is 3.33 percent. This illustrates that WOM is an intervening variable between dissatisfaction with brand image. This means that dissatisfaction occurs and followed by negative WOM will greatly contribute to the formation of corporate brand image.

While the direct influence of complaints (voice) on brand image larger (7.62 percent) than indirect influence through WOM (2.46 percent). This indicates that the role of WOM as an intervening variable is relatively weak. This means complaints and followed WOM make smaller contribution in the formation of brand image compared to direct complaints against brand image. This condition informs how big the opportunity for companies to manage complaints properly. So, the brand image will be in a good formed too.

Customer dissatisfaction also has a significant effect on customer's intention to switch. This shows that customers do not want to complain to the company but prefer to look for other flights in the future. This situation is also unfavorable to the airline itself. This shows the relatively low customer loyalty if they get dissatisfaction experience. The greater level of customer intention to switch then the lower number of customers and the possibility of decreasing revenue and profitability of the company. This condition will be more likely due to the increasing choice of airline and the lack of differentiation among the companies.

This is in line with the opinion of Griffin (2001) which states that the complaints are noticed and resolved quickly have a tendency to repurchase by 82 percent, otherwise customers who encounter major problems without complaints and tendency to repurchase only 9 percent. Gilly and Hansen (2001) show that effective complaint handling results in customer satisfaction and loyalty. Complaints of customer dissatisfaction are a great tool for studying customer complaints and important factors to improve business contacts (Crask et al., 2008). Empirical evidence suggests a correlation between customer dissatisfaction over product or service failures and customer complaints (Bearden and Teel, 2003; Halstead et al., 2000).

Further complaints toward customer intention to switch have significant effect, but the direction of its influence is negative. This situation indicates that complaints will affect the customers switching. The greater of customer complaints will cause intention to switch is lower and vice versa. This condition illustrates that if customers have complained, their mental burden will decrease, so the complaint does not cause them to switch.

Furthermore, if customer complaints are handled properly then the intention to switch will decrease. Conversely, if the complaint is handled badly, then the intention to switch will increase. This means that effort to increase the complaints of dissatisfy customers is a good business for airlines. Companies need to build tools to make customers easy and motivated to complain. Subsequent complaints can be managed to be something that is profitable for the company. Customer complaints if handled properly will affect the word of mouth, brand image and customers intention to switch.

Word of mouth (WOM) has a positive and significant influence on intention to switch on airline customers. When compared to the amount of influence it is seen that the influence of WOM toward intention to switch is greater than the influence of other variables. Based on the results of the research note that the magnitude of the direct influence of dissatisfaction toward intention to switch is 2.99 percent, and the indirect effect of dissatisfaction to intention to switch move through WOM is 6.34 percent. This indicates that WOM functions as an intervening variable. That is the dissatisfaction followed by negative WOM will greatly affect the customer's desire to look for other flights. Furthermore, the direct influence of complaints toward the intention to switch is $1.19 \%$ and the indirect effect of complaints on the intention to switch through WOM is $4.58 \%$. This condition further 
strengthens the position of WOM as an intervening variable. It means if the complaint is high and followed by negative WOM then the customer intention to switch to another flight will be greater.

This is in line with previous research which states that the risks to move and reduction in repeat purchase increase as the negative WOM probability increases (Bearden and Oliver, 2001, 237; GrønhaugKjell, 2000; Richins, 2000). Good complaints handling results in satisfaction and increases loyalty, and decreases the likelihood of negative WOM (GrønhaugKjell, 2000; Richins, 2000). This lowers the risk of moving and increases the likelihood of repeat purchase. Negative WOM is one result of customer complaint behavior. Hirschman (Nunziato, 2000) states that customer has two choices when dealing with a mismatch of expectations with performance received; i.e. complaining their dissatisfaction or leaving the company.

Conversely customer dissatisfaction and complaints will increasingly affect the brand image and the intention to switch if dissatisfaction and complaints are managed in line with the WOM itself. This illustrates that the management of dissatisfaction and complaints is very effective to create a positive WOM. If it creates positive WOM then the next will form a positive brand image and also the intention to switch will be reduced.

The role of WOM will be stronger because the greater use of social networks today and the future. The role of SMS, Facebook, MySpace, Twitter, Yahoo messenger and others will enhance the spread of WOM, both positive and negative. The magnitude of the coefficient of WOM influence on intention to switch indicates that the behavior of aviation customers is strongly influenced by WOM. Dissatisfaction and customer complaints are two variables that determine the amount of word of mouth of the airline customers. Furthermore, the outstanding WOM is affecting the brand image or corporate brand image is positioned in the minds of customers. WOM also determines the desire to move customers to other airlines.

Brand image does not affect the desire to move customers. This indicates that the brand image of the airline has not been formed in the minds of customers in the city of Padang. The results of this study indicate that loyal or moving customers do not consider the brand image of the airline. This means that customers are not vulnerable to brand image, because choosing any flight in the minds of customers is the same. This condition is due to the absence of strong brands among Indonesian airlines. Garuda and Mandala are more first enter the market was not able to build a strong brand image in the minds of customers. It also shows relatively high brand competition among airlines so that the mind share of airline brands is relatively equal or not controlled by certain airlines. The absence of clear differentiation among airlines also contributes to the inability of the brand image of an airline.

Switching cost has a significant influence on the intention to switch. This shows that the cost of switching or the difficulty of moving into one of the determinants of the desire to move customers. during normal conditions (regular time), customers can easily purchase tickets for various airlines. The purchase of tickets using the internet or through ticket sales provides a great opportunity for customers to choose their preferred airline. The results of this study also illustrate that switching barriers that built the company will effectively stem the customers intention to switch. Transfer barriers can be both financial and nonfinancial, depending on the amount of customer inclination, but from the results of the study also known that the customer is relatively easy to move from one flight to another flight. This means that airlines have not succeeded in building long-term relationship with their customers.

\section{Conclusions}

Based on the results of research conducted can be concluded that:

a. Dissatisfaction of airline customers does not affect to their complaints. This means that a dissatisfied customer will not make a complain to the company. But if there is dissatisfaction occur, then the customers tend to talk with friends, relatives or colleagues in the form of negative 
WOM. Besides, dissatisfaction build brand image and determine the customer intention to switch to other flights.

b. Customer complaint affects the word of mouth (WOM), brand image and customer intention to switch. Therefore, customer complaints can be an opportunity to build a positive WOM, positive brand image and hamper the customer's intention to switch to another airline.

c. Word of mouth (WOM) has a highly significant influence on brand image and intention to switch. The effect of dissatisfaction and complaints is directly smaller than the indirect influence of these two causal variables on brand image and the intention to switch. This indicates that WOM is an intervening variable on brand image and customer's willingness to move.

d. There is no strong brand image of airline companies in Indonesia, especially those serving the route Padang-Jakarta or Jakarta-Padang, so it does not affect to the customer intention to switch. Unclear differentiation between Indonesian airlines is estimated to be one of the causes.

e. The customers intention to switch will be higher if the switching cost perceived by customers is low, so there is no risk for them to change the brand.

In accordance with the above research results, it can be suggested as follows:

a. Companies have to do effort on building tools to facilitate customers complain, because customer dissatisfaction causes negative WOM, negative brand image and the desire to move to another flight.

b. The airlines need to change the customer's complaints into an opportunity to build an impression or surprise to the customer, as complaints handling affects WOM, brand image and customer intention to switch.

c. The role of WOM is very important, so it takes effort to manage it and avoid developing of negative WOM.

\section{References}

Aaker, J. L., (2001). Dimensions of brand personality. Journal of Marketing Research, 34, 347-356.

Ailawadi, K. L. \& Keller, K. L. (2004). Retail branding: Conceptual insights and research priorities. Journal of Retailing, 80(4), 331-342.

Anderson, E. W., \& Sullivan, M. W. (2001). The antecedents and consequences of customer satisfaction for firms. Marketing Science, 12, 125-143.

Andreason, A. R. (2001). A Taxonomy of consumer satisfaction/dissatisfaction measures. Journal of Consumer Affairs, 11, 11-24.

Andreassen, T. W. (2000). Antecedents to satisfaction with service recovery. European Journal of Marketing, 34(1), 156-175.

Andreasen A. R. and Best. (1999). Consumer complaint: Does business respond? Harvard Business Review, July-August, 55-101.

Bateson, John E. G. and K. Douglas Hoffman. (2000). Managing Services Marketing: Text and Readings. Fort Worth, TX: Dryden Press.

Bearden W. O. and R.L. Oliver. (2001). The role of public and private complaining in satisfaction with problem resolution. The Journal of Consumer Affairs, 19(2), 222-240.

Bearden W. O. and J. E. Teel. (2003). Selected determinants of customer satisfaction and complaint reports. Journal of Marketing Research, 20, 21-28.

Berry, L. L. \& Parasuraman, A. (2007). Marketing Service: Competing through Quality. New York: The Free Press.

Beerli, A., Martin, J. D., \& Quintana, A. (2004). A model of customer loyalty in the retail banking market. European Journal of Marketing, 38 (1/2), 253-275.

Boulding, W., Kalra, A., Staelin, R. \& Zeithaml, V. A. (2000). A dynamic process model of service quality: From expectations to behavioral intentions. Journal of Marketing Research, 30, February, 7-27.

Bowen, J. T., \& Chen, S. L. (2001). The relationship between customer loyalty and customer satisfaction. International Journal of Contemporary Hospitality Management, 2, 213-217. 
Brief, P. A. (2001). Attitudes in and Around Organizations. Sage Publications Inc.

Burnham, T. A., Frels, J. K., \& Mahajan, V. (2003). Consumer switching costs: A typology, antecedents, and consequences. Journal of the Academy of Marketing Science, 2, 109-126.

Caruana, A. (2002). Service Loyalty: The effects of service quality and the mediating role of customer satisfaction. European Journal of Marketing, 36(7/8), 811-28.

Chun, R., Davies, G., (2006). The influence of corporate character on customers and employees: Exploring similarities and differences. Academy of Marketing Science Journal, 34, 138-146.

Crask, Melvin, Fox, Richard J., \& Stout, Roy G. (2008). Marketing Research: Principles and Applications. Englewood Cliffs, NJ: Prentice Hall.

Cronin, J. J. and Taylor, S. A. (2002). Measuring service quality: A reexamination and extension. Journal of Marketing, 56(3), 55-68.

Day, G. S. (2000). The capabilities of market-driven organizations. Journal of Marketing, 58(4), 37-52.

Dick, A. S. \& Basu, K. (1999). Customer loyalty: Toward an integrated conceptual framework. Journal of the Academy of Marketing Science, 22(2), 99-113.

Doerpinghaus, Helen I. (2001). An analysis of complaint data in the automobile insurance industry. Journal of Risk and Insurance, 58, 120-127.

Edvardsson, Bo \& IngerRoos. (2006). Customer Complaints and Switching Behavior: A Study of Relationship Dynamics in A Telecommunication Company.

Fornell, C. (1999). A national customer satisfaction barometer: The Swedish experience. Journal of Marketing, 56, 6-21.

Fornell, Claes. (2007). The Satisfied Customer: Winners and Losers in the Battle for Buyer Preference. New York, NY: Palgrave-McMillan.

Gilly M. C. \& R. W. Hansen. (2001). Consumer complaint handling as a strategic marketing tool. Journal of Consumer Marketing, 2, 5-16.

Gremler, D. D., Gwinner, K. P., \& Brown, S. W. (2001). Generative positive word of mouth communication through customer-employee relationship. International Journal of Service Industry Management, 12(1), 45-59.

Griffin Jill. (2001). Customer Loyalty. How to Earn It. How to Keep It. New York: Lexington Books.

GrønhaugKjell. (2000). Risk indicators, Perceived risk and consumer's choice of information sources. The Swedish Journal of Economics, 7(2), 246-262.

GrønhaugKjell and Gilly, Mary C. (2001). A transaction cost approach to consumer dissatisfaction and complaint actions. Journal of Economic Psychology, 12, 165-183.

Halstead, D., Edward A. Morash, \& John Ozment. (2000). Comparing objective service failures and subjective complaints: An investigation of domino and halo effects. Journal of Business Research, 36,107-115.

Hart, C. W. L., Heskett, J. L. \& Sasser Jr., W. E. (2000). The profitable art of service recovery. Harvard Business Review, (July-August), 148-156.

James, G. M. I. and Richard, G. N. (2003). Firms reap what they sow: The effects of shared values and perceived organizational justice on customers' evaluations of complaint handling. Journal of Marketing, 67(1), 46-62.

Jones, M. A., Mothersbaugh, D. L., \& Betty, S. E. (2002). Why customers stay: Measuring the underlying dimensions of services switching costs and managing their differential strategic outcomes. Journal of Business Research, 55, 441-450.

Jones, T. O., Mothersbaugh, D. L., \& Beatty, S. E. (2000). Switching barriers and repurchase intentions in services. Journal of Retailing, 76(2), 259-274.

Jones, T. O., and Sasser, W. E. (2001). Why satisfied customers defect. Harvard Business Review, 73(6), 88-99.

Kotler, Philip, Armstrong, Gary, Saunders, John \& Wong, Veronica. (2007). Principles of Marketing, London, UK: Prentice Hall Europe.

Kucuk, Umit S., \& Krishnamurthy, Sandeep. (2007). An analysis of consumer power on the internet. Technovation, 27(1/2), 47-56. 
LaBarbera, P. A. \& Mazursky, D. (2003). A longitudinal assessment of consumer satisfaction, dissatisfaction: The dynamic aspect of cognitive process, Journal of Marketing Research, 20(4), 393-404.

Lewis, B. R. (2001). Service quality: An international comparison of bank customers' expectations and perceptions. Journal of Marketing Management, 7(1), 47-62.

Lewis, B. R., and Bingham, G. H., (2001). The Youth Market for Financial Services. International Journal of Bank Marketing, 9(2), 3-11.

Lewis, B. R. \& Spyrakopoulos, S. (2001). Service failures and recovery in retail banking: The customers' perspective. The International Journal of Bank Marketing, 19(1), 37-47.

Licen Indahwati Darsono. (2008). Hubungan Perceived Service Quality dan Loyalitas: Peran Trust dan Satisfction Sebagai Mediator. The 2nd National Conference UKWMS. Surabaya.

Mattila, Anna S. (2001). The effectiveness of service recovery in a multi-industry setting. The Journal of Services Marketing, 15(6), 583-597.

Mattila, A. S. (2001). The effectiveness of service recovery in a multi-industry setting. The Journal of Services Marketing, 15 (6/7), 583-596.

Mattila, A. S. (2004). The impact of service failures on customer loyalty: The moderating role of affective commitment. International Journal of Service Industry Management, 15(2), 134-149.

Murray, K. B. (2001). A test of services marketing theory: Consumer information acquisition activities. Journal of Marketing, 55, 10-25.

Nandan, S., (2005). An exploration of the brand identity-brand image linkage: A communications perspective. Journal of Brand Management, 12, 264-279.

Nayor, G. and Kleiser, S. B. (2000). Negative versus positive word-of-mouth. Journal of Consumer Satisfaction, Dissatisfaction and Complaining Behavior, 13, 26-36.

Newman, K. (2001). Interrogating SERVQUAL: A critical assessment of service quality measurement in a high street retail bank. International Journal of Bank Marketing, 19(3), 126-139.

Nunziato, C. Dawn. (2000). Exit, voice and values on the net. Berkeley Technology Law Journal, 15(2), 753-776.

O'Cass, A., \& Grace, D., (2004). Exploring consumer experiences with a service brand. The Journal of Product and Brand Management, 13, 257-267.

Oliver, R. (1999). Satisfaction: A Behavioral Perspective on the Consumer. New York: McGraw Hill.

Ping, R. A. (2000). Voice in business-to-business relationships: cost-of-exit and demographic antecedents. Journal of Retailing, 73, 261-281.

Reichheld, F. F. \& Sasser, W.E. Jr. (2000). Zero defections: Quality comes to services. Harvard Business Review, 68(5), 105-11.

Reisch, A. Lucia. (2003). Potentials, pitfalls, and policy implications of electronic consumption. Information \& Communication Technology Law, 12(2), 93-109.

Rezabakhsh, Behrang, Bornemann Daniel, Hansen Ursula \& Schrader Ulf. (2006). Consumer power: a comparison of the old economy and the internet economy. Journal of Consumer Policy, 29, 336.

Richins M. L. (1999). Negative word-of-mouth by dissatisfied consumers: A pilot study. Journal of Marketing, 47, 68-78.

Richins, M. L. (2000). Negative word-of-mouth by dissatisfied customers: A pilot study. Journal of Marketing, 47, 68-78.

Rowley, J., \& Dawes, J. (2000). Disloyalty: A closer look at non-loyal. Journal of Consumer Marketing, 17(6), 538-549.

Rust, R.T., \& Zahorik, A. J. (1999). Customer satisfaction, customer retention, and market share, Journal of Retailing, 69, Summer, 193-215.

Sharma, N., \& Patterson, P. G., (2000). Switching costs, alternative attractiveness and experience as moderators of relationship commitment in professional, consumer services. International Journal of Service Industry Management, 11(5), 470-490. 
Singh, Jagdip \& Wilkes, Robert E. (1999), When consumers complain: A path analysis of the key antecedents of consumer complaint response estimates. Journal of the Academy of Marketing Science, 24(4), 350-365.

Singh J. (1999), B. Voice, exit, and negative word-of-mouth behavior: An investigation across three service categories. Journal of the Academy of Marketing Science, 18(1), 1-15.

Singh J. (2000). A typology of consumer dissatisfaction response styles. Journal of Retailing, 66, 57-99.

Sivadas, E. \& Baker-Prewitt, F. L. (2000). An examination of the relationship between service quality, customer satisfaction, and store loyalty. International Journal of Retail \& Distribution Management, 28(2), 73-82.

Smith, A. K. \& R. N. Bolton. (2002). The effect of customers' emotional responses to service failures on their recovery effort evaluations and satisfaction judgments. Journal of the Academy of Marketing Science, 30, 5-23.

Soderlund, M. (2000). Customer satisfaction and its consequences on customer behavior revisited. International Journal of Services Industries Management, 9(2), 169-188.

Strauss, B., Schmidt, M., \& Schoeler, A. (2005). Customer Frustration in Loyalty Programs. Unpublished.

Tarp. (1999). Consumer complaint handling in America: An update study. Technical Assistance research programs, Washington D. C.

Zeithaml, V.A., L.L. Berry \& A. Parasuraman. (1999). The behavioral consequences of service quality. Journal of Marketing, 60 (2), 31-46. 